\title{
Correction to: Process Optimization for Development of a Novel Water Kefir Drink with High Antioxidant Activity and Potential Probiotic Properties from Russian Olive Fruit (Elaeagnus angustifolia)
}

\author{
Pariya Darvishzadeh $^{1}$ (D) Valérie Orsat ${ }^{1} \cdot$ José Luis Martinez $^{2}$ \\ Published online: 23 January 2021 \\ (C) Springer Science+Business Media, LLC, part of Springer Nature 2021
}

Correction to: Food Bioprocess Technol

https://doi.org/10.1007/s11947-020-02563-1

The original version of this article unfortunately contained some mistakes.

There is a problem in Figure 1a and b, as there is extra green box that covers some data for the image.

The original paper has been corrected.

Publisher's Note Springer Nature remains neutral with regard to jurisdictional claims in published maps and institutional affiliations.

The online version of the original article can be found at https://doi.org/ 10.1007/s1 1947-020-02563-1

Pariya Darvishzadeh

Pariya.Darvishzadehboroojeni@mail.mcgill.ca

1 Department of Bioresource Engineering, McGill University, Montreal, Quebec, Canada

2 Department of Biotechnology and Biomedicine, Technical University of Denmark (DTU), Lyngby, Denmark 